\title{
Linking dietary energy and skeletal development in the horse
}

\author{
William Burton Staniar ${ }^{1}$ \\ ${ }^{1}$ Department of Dairy \& Animal Science - The Pennsylvania State University, University Park, Pennsylvania, USA.
}

ABSTRACT - Athletic production is what is sought from the horse. As mammary development is important to the dairy cow, skeletal development is important to horses meeting their production goals. As any integrative physiologist will appreciate, the variables that come together to result in optimal skeletal development are complex. Nutrition is one of these, and it contains two broad variables; the supply of dietary nutrients and energy. This presentation will focus on dietary energy and its links with skeletal development. I propose that it is not simply the amount of dietary energy, but the way and from that that energy is supplied that impacts skeletal development. Through an understanding of how dietary energy impact skeletal development, more precise feeding management strategies can be developed to reduce the risk of skeletal abnormalities and even potentially improve skeletal integrity.

Key Words: cartilage, equine, glucose, growth, insulin, somatotropic axis

\section{Vinculação de energia na dieta e desenvolvimento do esqueleto do cavalo}

\begin{abstract}
RESUMO - Produção atlética é o que se exige do cavalo. Do mesmo modo que o desenvolvimento das glândulas mamárias é importante para vaca leiteira, o desenvolvimento do esqueleto é importante para os cavalos atingirem as metas de produção. Como qualquer fisiologista integrador vai apreciar, as variáveis necessárias para se atingir o desenvolvimento ideal do esqueleto são complexas. A nutrição é uma destas variáveis que contém outras duas mais amplas: fornecimento de nutrientes e energia da dieta. Esta apresentação irá focar na energia da dieta e seus vínculos com o desenvolvimento do esqueleto. Proponho que não é simplesmente a quantidade de energia da dieta, mas a maneira como essa energia será fornecida e quais serão os impactos sobre o desenvolvimento do esqueleto. O entendimento do impacto da energia da dieta sobre o desenvolvimento do esqueleto pode gerar estratégias de gestão de alimentação mais precisas para reduzir o risco de anormalidades esqueléticas e até melhorar potencialmente a integridade do esqueleto.
\end{abstract}

Palavras-chave: cartilagem, crescimento, eixo somatotrófico, equinos, glicose, insulina

\section{Introduction}

Nutrition is a critical part of the horse's environment and its connection to growth is articulated well by one definition of growth given by D'Arcy Thompson.

"the complicated results of the chemistry of nutrition." (Thompson, 1942)

The skeleton is the framework off of which the athletic potential of the horse is built. The greatest impact that nutrition can have on cartilage and bone is during skeletal maturation and development. The rate of skeletal growth declines exponentially from a peak just prior to parturition to a steady and very slow turnover at the point of skeletal maturity. Dietary energy plays an important role in controlling the rate of skeletal growth, and hence energy and growth rate are inherently tied to one another. Even recent research indicates that the ability to separate dietary energy and growth as causes of skeletal abnormalities is difficult (Donabedian et al., 2006). This difficulty can be attributed to basic concepts of causality, but it is suffice to say that skeletal development is dependent on numerous dietary factors, and recommended adjustment of any one of these has not had a significant impact on the problem of developmental orthopedic disease (DOD) (Jackson \& Pagan, 1993). The objectives of this paper are to provide: 1 ) an overview of the links between dietary energy and skeletal development, 2) a hypothesis based on these links that describes how dietary energy may be positively or negatively affect skeletal development and ultimately skeletal health.

Most of the current research in the area of equine skeletal development is focused on understanding the mechanisms that control the turnover of cartilage and bone. Questions that are being addressed include: How does the 
pattern of growth affect the quality of skeletal development? Do different dietary energy sources provide different cues to the cartilage and bone? Are there particular windows of time during development when specific feeds should be provided, and conversely are there times when some feeds or nutrients should not be fed? How do those feeding horses integrate an understanding of nutrient supply and metabolic signals to optimize skeletal development?

Before examining dietary energy alone it is important to consider all the factors that are or may be influential to skeletal development. Most broadly these are genetics and the environment. Genetic selection and management protocols utilized in raising young horses are often aimed at supporting precocious growth due to the perceived association of size with athletic prowess. Dyschondroplasia (DCP) and osteochondrosis (OC), two forms of developmental orthopedic disease (DOD), might be regarded as a side-effect of selection for precocious speed, hence precocious growth, and an exaggeration of the physiologic mechanisms that control growth (Kronfeld, 1957, 2003). As an illustrative example, serum concentrations of growth hormone (GH) and insulin-like growth factor I (IGF-I), central hormones in the somatotropic axis (STA), were higher in pigs selected for rapid growth than in those selected for low growth (Hill, 1990). It is not much of a stretch to hypothesize that similar selection pressures in the equine industry have led to similar changes in regulatory pathways.

Selection for growth is likely to contribute to the heritability of osteochondrosis. Heritability has been estimated from 23 to $52 \%$ in Scandanavian trotters (Grondahl \& Dolvik, 1993; Philipsson et al., 1993). Yet, no mode of inheritance has been identified. In other species, such as the pig, dog and sheep, evidence of increased OC lesions, has been found in breeds with rapid growth rates compared with the slower growing breeds (Goedegebuure et al., 1980; Hill, 1990; Valentino et al., 1999). A likely positive genetic association between athletic performance and OC virtually eliminates genetic management of OC. Consequently interest shifts to manageable environmental factors, such as nutrition and controlled exercise, which may be necessary in combination with genetic predisposition to disturb chondrocyte maturation (Torre, 1999).

The equine diet is composed of a mixture of plant materials, whether forages or grain. On a dry matter basis carbohydrates make up roughly $70-85 \%$ of the chemical composition of plants. Plants contain both structural and non-structural carbohydrates. Non-structural carbohydrates are hydrolyzed and absorbed as glucose across the equine small intestine. Structural carbohydrates are fermented and result in the production of volatile fatty acids which are absorbed in the equine hindgut. Because carbohydrates are a ubiquitous form of energy, the horse, not unlike most living organisms including ourselves, uses plasma glucose availability as an indicator of energy availability, and changes metabolism in response. A simplified illustration of this is the start of reproductive cycling in the broodmare and rapid growth of yearlings on rich spring pasture. The non-structural carbohydrates are higher and the pasture more digestible, and this energy availability is a signal to the horse to increase the energy utilizing processes such as reproduction and growth. There are of course other changing signals such as day length and temperature, but these are also evolved proxies of energy availability. Taking the next step, it is important to understand how tissues, particularly the skeleton, interpret changes in energy signaling.

\section{Dietary energy and skeletal growth}

Nutrition is associated with two components of skeletal development. First, nutrients act as a supply of building materials. Bone and cartilage are made up of a mixture of organic and inorganic molecules, the majority of which are protein and minerals. The requirement for growth for these nutrients depends on the rate of growth and the turnover of skeletal tissues. An analogy would be the steel, rivets, and plastic used for building the frame of a racecar. If there is not sufficient steel provided, either the car has to be built smaller, or the frame weakened. Second, nutrients and dietary energy act as metabolic signals for cartilage and bone cells. In this role they act as cues, signaling the skeletal tissue as to the rate it should be developing based on the current nutritional environment. Stretching the car analogy a bit, you might see the production of cars decrease at times when fuel required for powering robots on assembly line was insufficient. While both the material and energy supply are important, this paper will focus on the energy and its impact on skeletal metabolism.

Metabolism is the combination of anabolism (building) and catabolism (breaking down) of tissues in the body. When the overall rate of anabolism is greater than catabolism growth occurs. Most organisms, including the horse, have a complex chemical communication network, the STA, which regulates metabolism in response to the environment. Understanding how growth is regulated through the STA provides those raising horses with a tool to manage their animals' environment, and by so doing; optimize growth for health and athletic potential. While nutrients are critical in supplying the building blocks for various tissues, energy availability is usually the limiting factor as to the rate at which growth occurs. By regulating plasma glucose concentrations and patterns through moderating dietary 
nonstructural and structural carbohydrates, as well as fat, those feeding the horse have a certain level of control over the STA. This hypothesis is a central concept behind the development of concentrates based on fat and fiber as opposed to sugar and starch for horses at risk of DOD.

Some of the most biologically conserved molecules are those associated with the signaling of energy availability. Examples include glucose, insulin, growth hormone and IGF-I (Stoka, 1999). All of these are also important signals regulating cartilage and bone development (Orth, 1999). It has further been suggested that abnormalities in the concentrations of these signals to skeletal issues may be associated with developmental problems (Shingleton et al., 1997; Staniar et al., 2007). All of this has led to many more questions than answers and a general pessimism that nutritional management of dietary energy can be used to address skeletal development. How does modifying each of these variables influence the circulating patterns of metabolic signals? Are there patterns of metabolic signals that can be associated with developmental orthopedic disease or conversely improved skeletal development?

In the rapidly developing bones of the newborn foal, the growth plate cartilage plays an important role in the ultimate development of longitudinal bone growth. This role is important both for the structure of the actual bone, and for the integrity of the articular cartilage. The chondrocytes that make up the growth plate cartilage go through several phases of development that are vital to the final architecture of the bone. These cells are controlled by a multitude of different endocrine, paracrine, and autocrine factors, directing them through development (Orth, 1999). Insulin-like growth factor-I is one of the hormones that appear to be important in the maturation of chondrocytes, and it is the only one that affects all stages of development; proliferation, differentiation, and apoptosis (Green et al., 1985). GH and insulin exhibit significant control over the release of IGF-I from the liver, such that changes in GH and insulin lead directly to changes in the concentration of IGF-I (Jeffcott \& Savage, 1996).

The connection between rate of growth and the STA is seen in figure 1 . This data was collected from Thoroughbreds from birth through 18 mo of age (Staniar et al., 2007). This data was collected in northern Virginia, and the patterns follow what might be expected based on the climatic conditions in this region. Based on the $\mathrm{x}$-axis, those samples around day of year 400 were taken in the coldest part of the winter, while samples around day of year 500 were taken at the peak of spring.

To further investigate the links between nutrition and the STA, two key studies were conducted using Thoroughbred foals from birth to 16 months of age (Staniar, 2001). The first study examined changes in growth and IGFI monthly. Average daily gain of the foals during the first year and a half of life was positively associated with circulating IGF-I concentrations $(\mathrm{P}<0.001)$. During periods of rapid growth in the first three months of life, and the following spring, circulating IGF-I concentrations were higher in foals fed a high starch versus the fat and fiber supplement $(\mathrm{P}<0.001)$. The second study addressed the short term effects of a meal on glucose, insulin, growth hormone, and IGF-I (Staniar et al., 2001b). The effect of meals was revealed by changes in plasma glucose and insulin with time $(\mathrm{P}<0.0001)$. Plasma GH exhibited 6.6 \pm 0.6 GH secretory episodes averaging $15 \pm 1.9 \mathrm{ng} / \mathrm{ml}$ per day. Four distinct secretory episodes, common to all 12 yearlings examined, suggested a synchronizing effect of the feeding-

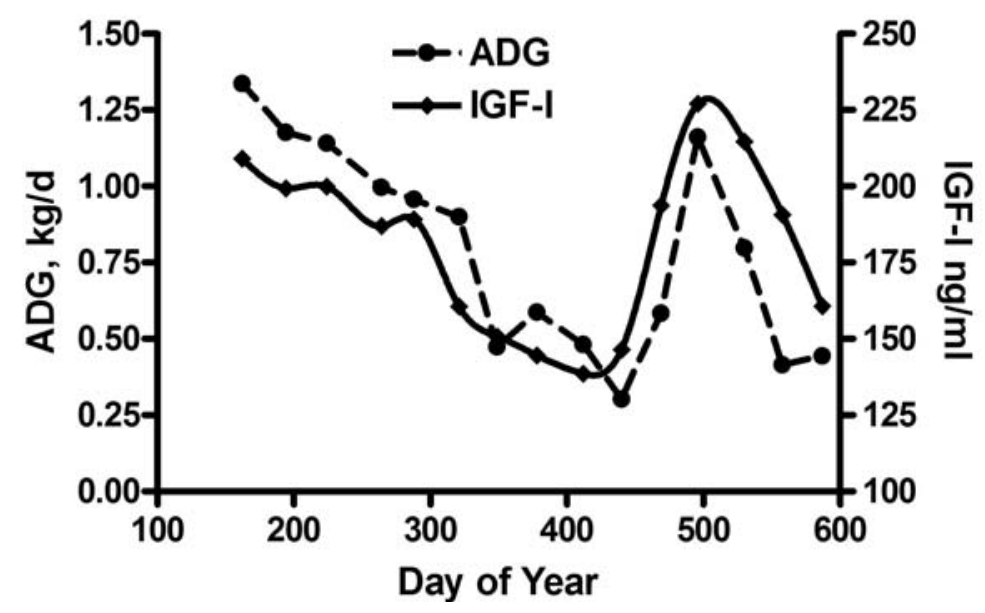

Figure 1 - Average daily gain (ADG) and circulating IGF-I in foals from birth through 18 mo of age. The x-axis is day of year, with year 2 beginning with day of year 366. 
fasting cycle. Plasma IGF-I concentration was $239 \pm 3.8 \mathrm{ng} / \mathrm{ml}$ with no feed or meal effect. These two studies demonstrate the association of the STA with growth in the horse, as well as a possible influence of diet on the STA. The question that remains is how to utilize this information in formulating diets and feeding strategies for horses that will reduce the risk of DOD or even improve skeletal development.

\section{Reducing risk and optimizing growth}

In addressing the above question, we will first examine the evidence of a connection between dietary energy, rapid growth, and DOD. There is a body of literature linking high glycemic and energy diets with DOD, and research into the perturbations to metabolism caused by daily feeding of two starch rich meals to the horse (Jeffcott \& Henson, 1998; Williams et al., 2001; Kronfeld \& Harris, 2003). The moderation of the glycemic response is critical, because in horses fed twice daily, these perturbations in glucose and insulin result in a feeding/fasting cycle of hormones and metabolites that influence a myriad of metabolic systems. A meal that results in a high glycemic response will also influence insulin, thyroid hormones, GH, and IGF-I. These are all important players in the STA, and most act to up-regulate the rate of skeletal development.

Rapid growth rates and high-energy intakes are regularly included in the multiple causes of DOD. The direct relationship of these causes with the various manifestations of DOD has proven elusive. The difficulty is due to the complexities that relate energy intake to growth rate and normal or abnormal skeletal development. Developmental orthopedic disease is a major economic and esthetic problem in the horse industry (Jeffcott, 1996; McIlwraith, 2001). Research on the multiple causes of OC and DOD has advanced considerably, yet the mechanisms behind nutrition's and growth's influence remain unclear (Jeffcott \& Savage, 1996; McIlwraith, 2001). In basic epidemiologic terms, nutrition is only one of a number of causative components that come together to form a causative mechanism sufficient for DOD to occur (Rothman, 2002).

Numerous nutrients related to the growth and metabolism of cartilage have been highlighted over the years, but in particular are energy, protein, calcium, phosphorus, copper and zinc (Kronfeld et al., 1990; McIlwraith, 2001). Many studies have been undertaken and suggested to either support or refute the role of a particular nutrient. Nonetheless, caution needs to be taken when evaluating and extrapolating from the various nutritional studies mentioned below. In particular it is important to note these points:

- Feeds with the same overall energy content may have very different metabolic effects in the animal based on energy source (Staniar et al., 2001a; Treiber et al., 2005a).

- Dietary energy is provided by the four principle dietary energy sources (hydrolysable carbohydrates, fermentable fibers, oils/fats, and protein). The relative proportions and characteristics of these sources within a particular feed may influence the physiological and biochemical responses to such a feed.

- Protein sources differ with respect to site of digestion and how the body responds metabolically to the products of digestion (Staniar et al., 2001c).

- Background differences in the climate, management practices, and pasture type may influence the physiologic response and therefore clinical outcome to a particular dietary manipulation, as can breed, etc. (Staniar \& Cubitt, 2004).

Epidemiological studies in the field are especially useful when they consider the make up of the nutrient supply, the balance of energetic efficiency, and the ways that meals or diets are provided, rather than purely total intakes. Difficulties with adequate subject numbers and availability of reliable individual data can be major limitations for such studies. We suggest that to better resolve the role that growth rate and energy intake might play in DOD, both need to be investigated in much more detail. High dietary energy intake has been associated with an increased incidence of DOD in several studies:

- Feeding 129\% NRC energy requirements to foals from 130 days of age resulted in an increased incidence of lesions compared with the control group (fed 100\%) or those fed $126 \%$ of the National Research Council's recommendations (NRC, 1989) for protein (Savage et al., 1993). Multiple lesions of DCP were found on gross post mortem in 11 foals fed the high DE diet; one fed the high protein diet and one fed the control diet. Histological lesions of DCP were found in 18 foals: in all 12 of the high $\mathrm{DE}$, four of the high protein and 2 of the control foals.

- Cymbaluk et al. (1990) reported ad libitum cube feeding resulted in a higher incidence of conformational and locomotor abnormalities at 25 months of age than the more restricted diet.

- Glade \& Belling (1984) compared the growth of foals fed either 70 or $130 \%$ of the NRC (1978) recommended levels for energy. The $130 \%$ fed group showed developmental disturbances of growth plates, whereas the restricted group had normal development of the bones but at reduced rate.

The lesions produced in some of these studies are not directly comparable to those found in the field, and many field studies have reported foals being fed much higher 
energy intakes without an apparent increase in clinical incidence (Kronfeld et al., 1990). This may be linked to the background level of predisposition within the individuals, nature of the energy being provided and the balance of the diet.

A number of studies have linked rapid growth rates, and often by inference excessive feed/energy intake with an increased incidence of DOD. Feeding management at successful Thoroughbred breeding facilities dictates that foals be consuming a portion of their dam's feed by 2 months of age. These foals are weaned between $4-6$ months, at which time they are fed on their own. It is likely that the selection for precocious growth has led to an amplification in expression of factors in the STA - a set of regulatory hormones that includes insulin, GH, IGF-I, IGF-II, and the IGF binding proteins (IGFBPs). Here are just a few of the samples that link rapid growth with skeletal abnormalities.

- A detailed longitudinal growth study of 18 colts split into either limited or ad libitum fed groups illustrated more rapid growth and a higher incidence of clinically assessed conformational and musculoskeletal abnormalities in the ad libitum fed group (Cymbaluk et al., 1990).

- Thoroughbred foals that developed cervical vertebral malformation tended to have higher weights and wither heights during particular periods of growth when compared to a group of normal foals (Ruff et al., 1993).

- Osteochondrotic lesions were radiographically diagnosed in 27 Thoroughbred foals that also exhibited more rapid growth than 244 normal foals, between 3 to 8 months of age (Pagan \& Jackson, 1996).

- A group of 15 Warmblood foals with osteochondrotic lesions in their stifle had significantly higher weight gains during particular periods of growth when compared to a group of 28 foals with no lesions (van Weeren et al., 1999).

- A survey of Standardbreds in Sweden suggested that foals that developed radiographic signs of tarsocrural joint OC had a higher body weight (BW) at birth and continued to be heavier and have a significantly higher average daily weight gain than did the unaffected foals, (Sandgren et al., 1993). This may indicate a genetic predisposition as these animals also had a larger frame than the horses without tarsocrural OC. Interestingly, no significant differences were found in weight or ADG in those affected or unaffected with Fetlock lesions.

Taken together these studies indicate a connection of rapid growth with certain types of DOD. Current approaches to reduce the occurrence of DOD lack strength because the molecular mechanisms that link rapid growth and the events that initiate DOD have not been determined. In addition, the multifactorial nature of this syndrome means that the connection is not always direct, for example in some animals a rapid growth rate could be a predisposing factor, but expression might only occur when a number of other factors are superimposed (e.g., as a hypothetical example in those genetically predisposed to rapid growth, whose dams were fed inadequate copper during gestation and then the foals were fed an unbalanced diet as weanlings). Rapid growth may affect bone maturation directly or indirectly due to the mechanical overload or disturbances in nutritional supply and hormonal balance. These and other factors associated with rapid growth rates therefore may be involved to a greater or lesser extent in individual cases. It may be that the sometimes-inconsistent results found between studies are just a result of the nature of this condition.

It may be that the vehicle of grain and molasses has been at fault. Daily feeding of two meals abundant in starch and sugar sets up a feeding-fasting cycle of metabolites and hormones (Kronfeld, 1998; Williams et al., 2001). The amplitude of fluctuation in plasma glucose and insulin is reduced when starch and sugar are replaced by fat and fiber in the meal (Williams et al., 2001). An analogous example is the reduction in the NSC concentration of the meal, replacing lost energy with increased fat concentration. Relevance of the feeding-fasting cycle to DCP and DOD has been placed previously on glucose and insulin (Ralston, 1996), GH (Kronfeld et al., 1990), or IGF-I (Burk et al., 2003; Staniar et al., 2003). Plasma glucose and insulin have served mainly as triggering factors for the STA, with GH and IGF-I acting directly as regulators of chondrocyte metabolism and maturation (Treiber et al., 2005b).

Typical grain-molasses feeds contain abundant starch and sugar. They exaggerate oscillations of the feedingfasting cycle, which are reduced by replacement of starch and sugar with fat and fiber. The key feature of a fat and fiber concentrate is an array of fiber sources, which is intended to promote a diverse microbial population in the equine hindgut to achieve the energy concentration of a typical feed required fortification with dietary fat. Advantages of a fat and fiber feed over a feed formulated to mimic typical grain-molasses feeds have been shown in growth curves of yearlings, in milk composition, and in moderation of the glucose and insulin responses to feeding (Williams et al., 2001).

\section{Conclusions}

The horse evolved over a period of approximately 60 million years to utilize forage as an effective source of energy and nutrients. Animals were free to migrate to where 
the grass was greener, or evolved genotypes that allowed them to survive in a feast or famine environment. Over a period of only 6,000 years, man has made a significant change to this environment, by keeping horses in one place and providing them a constant source of high energy carbohydrates. It is likely that many of the problems with growth we have with horses today are related to nutritional and management strategies developed before we had as detailed an understanding of equine metabolism as we do today.

With the advent of exciting developments in the fields of genomics, proteomics, and even metabolomics, researchers are gaining a new perspective on metabolic regulatory mechanisms in the horse. As scientists our goal should be to acquire knowledge about the molecular mechanisms linking nutrition with growth. One area where this research is likely to help is providing management strategies that more effectively avoid problems such as osteochondrosis.Current management strategies advocate constantly monitoring growth by measuring weight, and maintaining smooth growth curves. Yet by the time changes in weight are measurable a considerable amount of change has likely occurred at the molecular level. With our growing understanding of the relationship between the horse and its environment we are able to develop "proactive" management strategies. These are no longer a reaction to for example a change in weight, but instead a strategy to prevent that negative change from ever occurring. I have not suggested a new way of growing foals, but instead a new perspective on systems that evolved over a long period. Utilizing this understanding we can move forward to produce healthier and more athletically productive animals.

Finally, a hypothesis based on these links that describes how dietary energy may be positively or negatively affect skeletal development and ultimately skeletal health. Growing horses fed a diet that provides sufficient energy and nutrients in a manner that allows for a relatively constant rate of growth without a meal feeding disturbance to hormones and metabolites will have a reduced risk of DOD because the nutritional causative component will be removed from the causative mechanism.

\section{References}

BURK, R.; STANIAR, W.B.; KRONFELD, D.S. et al. Insulinlike growth factor binding proteins fluctuate with age in growing Thoroughbreds. East Lansing, Michigan: Equine Nutrition and Physiology Society, 2003. 84p.

CYMBALUK, N.F.; CHRISTISON, G.I.; LEACH, D.H. Longitudinal growth analysis of horses following limited and ad libitum feeding. Equine Veterinary Journal, v.22, p.198-204, 1990.
DONABEDIAN, M.; FLEURANCE, G.; PERONA, G. et al. Effect of fast vs. moderate growth rate related to nutrient intake on developmental orthopaedic disease in the horse. Animal Research, v.55, p.471-486, 2006.

GLADE, M.J.; BELLING JR., T.H. Growth plate cartilage metabolism, morphology and biochemical composition in overand underfed horses. Growth, v.48, p.473-482, 1984.

GOEDEGEBUURE, S.A.; HANI, H.J.; VAN DER VALK, P.C. et al. Osteochondrosis in six breeds of slaughter pigs. I. A morphological investigation of the status of osteochondrosis in relation to breed and level of feeding. Veterinary Quarterly, v.2, p.28-41, 1980 .

GREEN, H.; MORIKAWA, M.; NIXON, T. A dual effector theory of growth-hormone action. Differentiation, v.29, p.195-198, 1985.

GRONDAHL, A.M.; DOLVIK, M.I. Heritability estimations of osteochondrosis in the tibiotarsal joint and of bony fragments in the palmar/plantar portion of the metacarpal and metatarsalphalangeal joints of horses. Journal of the American Veterinary Medical Association, v.203, p.101104, 1993.

HILL, M.A. Causes of degenerative joint disease (osteoarthrosis) and dyschondroplasia (osteochondrosis) in pigs. Journal of the American Veterinary Medical Association, v.197, p.107-113, 1990.

JACKSON, S.G.; PAGAN, J.D. Developmental orthopedic disease. Multiple causes - no sure cures. Journal of Equine Veterinary Science, v.13, p.9-10, 1993.

JEFFCOTT, L.B. Osteochondrosis - an international problem for the horse industry. Journal of Equine Veterinary Science v. 16p. 32-37, 1996.

JEFFCOTT, L.B.; HENSON, F.M.D. Studies on growth cartilage in the horse and their application to aetiopathogenesis of dyschondroplasia (osteochondrosis). The Veterinary Journal, v.156, p.177-192, 1998.

JEFFCOTT, L.B.; SAVAGE, C.J. Nutrition and the development of osteochondrosis (dyschondroplasia). Pferdeheilkunde, v.12, p.338-342, 1996.

KRONFELD, D.S. Growth hormone administration to pregnant sheep. Cornell Veterinarian, v.67, p.151, 1957.

KRONFELD, D.S. Clinical assessment of nutritional status of the horse. In: WATSON, T. (Ed.) Metabolic and endocrine problems of the horse. London: W. B. Saunders Company, 1998. p.185-217.

KRONFELD, D.S. Speed-limit: side-effects of breeding for speed. The Blood-Horse, v.134, p.1118-1122, 2003.

KRONFELD, D.S.; HARRIS, P.A. Equine grain-associated disorders. Compendium on Continuing Education for the Practicing Veterinarian, v.25, p.974-983, 2003.

KRONFELD, D.S.; MEACHEM, T.N.; DONOGHUE, S. Dietary aspects of developmental orthopedic disease in young horses. Veterinary Clinics of North America: Equine Practice, v.6, p.451-465, 1990.

MCILWRAITH, C.W. Developmental orthopedic disease (DOD) in horses - a multifactorial process. In: EQUINE NUTRITION AND PHYSIOLOGY SYMPOSIUM, 17., 2001, Lexington, Kentucky. Proceedings... Lexington: 2001. p.2-23.

NATIONAL RESEARCH COUNCIL - NRC. Nutrient requirements of horses. 4.ed. Washington, D.C.: National Academy of Sciences, 1978.

NATIONAL RESEARCH COUNCIL - NRC. Nutrient requirements of horses. 5.ed. Washington, D.C.: National Academy Press, 1989.

ORTH, M.W. The regulation of growth plate cartilage turnover. Journal of Animal Science, v.77, p.183-189, 1999 (Suppl.).

PAGAN, J.D.; JACKSON, S.G. The incidence of developmental orthopedic disease on a Kentucky thoroughbred farm. Pferdeheilkunde, v.12, p.351-354, 1996.

PHILIPSSON, J.; ANDREASSON, E.; SANDGREN, B. et al. Osteochondrosis in the tarsocrural joint and osteochondral 
fragmanets in the fetlock joints of Stanadrbred trotters. II. Heritability. Equine Veterinary Journal, v.16, p.38-44, 1993 (suppl.).

RALSTON, S.L. Hyperglycemia/hyperinsulimia after feeding a meal of grain to young horses with osteochondritis dissecans (OCD) lesions. Pferdeheilkunde, v.12, p.320-322, 1996.

ROTHMAN, K.J. Epidemiology: an introduction. New York: Oxford University Press, 2002.

RUFF, S.J.; WOOD, C.H.; AARON, D.K. et al. A comparison of growth rates of normal Thoroughbred foals and foals diagnosed with cervical vertebral malformation. Journal of Equine Veterinary Science, v.13, p.596-599, 1993.

SANDGREN, B.; DALIN, G.; CARLSTEN, J. et al. Development of osteochondrosis in the tarsocrural joint and osteochondral fragments in the fetlock joints in standardbred trotters. II. Body measurements and clinical findings. Equine Veterinary Journal, v.16, p.38-41, 1993 (suppl.).

SAVAGE, C.J.; MCCARTHY, R.N.; JEFFCOTT, L.B. Effects of dietary energy and protein on induction of dyschondroplasia in foals. Equine Veterinary Journal, v.16, p.74-79, 1993.

SHINGLETON, W.D.; MACKIE, E.J.; CAWSTON, T.E. et al. Cartilage canals in equine articular/epiphyseal growth cartilage and a possible association with dyschondroplasia. Equine Veterinary Journal, v.29, p.360-364, 1997.

STANIAR, W.B. Growth and the somatotropic axis in young Thoroughbreds. 2001. Dissertation, Virginia Polytechnic Institute and State University, Blacksburg.

STANIAR, W.B.; CUBITT, T.A. Forage energy and nutrient fluctuations relative to growth in horses. Roanoke, Virginia: American Forage and Grasslands Council, 2004. p.172-178.

STANIAR, W.B.; KRONFELD, D.S.; AKERS, R.M. et al. Insulinlike growth factor I in growing thoroughbreds. Journal of Animal Physiology and Animal Nutrition, v.91, p.390399, 2007.

STANIAR, W.B.; KRONFELD, D.S.; AKERS, R.M. et al. Dietary fat and fiber influence plasma insulin-like growth factorI: an endocrine link between diet and osteochondrosis. Boston: American Academy of Veterinary Nutrition, 2001a. p.13-14.

STANIAR, W.B.; KRONFELD, D.S.; AKERS, R.M. et al. Feed composition affects the somatotropic axis in growing
Thoroughbreds. Blacksburg: Virginia Polytechnic Institute and State University, 2001b.

STANIAR, W.B.; KRONFELD, D.S.; SPLAN, R.K. et al. Environmental influences on Thoroughbred growth. Journal of Animal Science, 2003. (In preparation).

STANIAR, W.B.; KRONFELD, D.S.; WILSON, J.A. et al. Growth of thoroughbreds fed a low-protein supplement fortified with lysine and threonine. Journal of Animal Science v. 79p. 2143-2151, 2001c.

STOKA, A.M. Phylogeny and evolution of chemical communication: an endocrine approach. Journal of Molecular Endocrinology, v.22, p.207-225, 1999.

THOMPSON, D.A.W. On growth and form: a new edition. Cambridge: Cambridge University Press, 1942.

TORRE, F. Osteochondrosis and poor performance: current knowledge and perspectives. Paris: World Equine Veterinary Association Congress, 1999. p.143-146.

TREIBER, K.H.; BOSTON, R.C.; KRONFELD, D.S. et al. Insulin resistance and compensation in Thoroughbred weanlings adapted to high-glycemic meals. Journal of Animal Science, v.83, p.2357-2364, 2005a.

TREIBER, K.H.; KRONFELD, D.S.; STANIAR, W.B. et al. Growth hormone and IGF-I in Thoroughbred weanlings are affected by diet. In: MEETING ON MILK-FED FARM AND COMPANION ANIMALS: Basic Aspects and Practice for the Future, 2005, Bern, Switzerland. Proceedings... Bern: 2005b. p.39.

VALENTINO, L.W.; LILLICH, J.D.; GAUGHAN, E.M. et al. Radiographic prevelence of osteochondrosis in yearling feral horses. Veterinary Compendium of Orthopedic Traumatology, v.12, p.151-155, 1999.

VAN WEEREN, P.R.; SLOET VAN OLDRUITENBORGHOOSTERBAAN, M.M.; BARNEVELD, A. The influence of birth weight, rate of gain and final achieved height and sex on the development of osteochondrotic lesions in a population of genetically predisposed Warmblood foals. Equine Veterinary Journal, v.31, p.26-30, 1999 (suppl.).

WILLIAMS, C.A.; KRONFELD, D.S.; STANIAR, W.B. et al. Plasma glucose and insulin responses of Thoroughbred mares fed a meal high in starch and sugar or fat and fiber. Journal of Animal Science, v.79, p.2196-2201, 2001. 